\title{
Magenta red, Castellani's paint and an array of autumn colours
}

It's that time of year again. The weather is turning colder and multi-coloured leaves cover the ground. The selection of articles for this October issue of The Journal of Laryngology \& Otology is sure to further invigorate your senses.

'Itchy ears' are one of the most frequently encountered symptoms in the ENT clinic. In this month's issue, old remedies are revived with a study by Babakurban et al. ${ }^{1}$ Castellani's paint, formulated in 1905 by Aldo Castellani (Italian physician, 1877-1971), has long been used in dermatological practice. One of its active ingredients, basic fuchsin, which has local anaesthetic, bactericidal and fungicidal properties, is also responsible for imparting a bright magenta red colour to the compound. In this study, the authors found that Castellani's paint is an effective treatment for itchy ears, and does not affect the normal microbial flora of the external auditory canal, unlike topical steroids. ${ }^{2}$

ENT training is currently a topical issue. An online general practitioner trainee survey conducted by Easto and Reddy, with a response rate of 60.5 per cent, found that nearly 60 per cent of general practitioner trainees spent no time in ENT posts in post-graduate training, and 65 per cent of general practitioner trainees received no formal ENT teaching after medical school. ${ }^{3}$ However, 93.4 per cent of trainees were keen to attend a 1-day ENT course if provided locally. Locally available courses for general practitioner trainees made up of local experts is therefore encouraged, especially given that within primary care $15-20$ per cent of adult presentations and up to 50 per cent of paediatric presentations are ENT-related.

Part of such training may include the use of simulation. Previous studies have shown that simulation provides an opportunity for doctors to learn and practice important ENT skills in a safe environment. ${ }^{4,5}$ In a related series of articles in this month's issue, Isaacson et al. demonstrate the effectiveness of an $e x$ vivo ovine model for suspension microlaryngoscopy training, Clark et al. report the development and validation of a low-cost microsurgery ear trainer, and Avnstorp et al. show that the introduction of emergency cricothyroidotomy simulation training in Zimbabwe saves lives. ${ }^{6-8}$ This current series of articles is noteworthy in terms of simulator development and highlights the importance of simulation training in lowincome settings.
Hyperbaric oxygen for the treatment of idiopathic sudden sensorineural hearing loss is revisited in a study by Alimoglu and Inci. ${ }^{9}$ The authors conclude that hyperbaric oxygen therapy may be effective as a salvage treatment following failed corticosteroid therapy. However, the limited availability, cost and lack of high-level evidence probably make it impractical at present. ${ }^{10}$

Historically, there has been a dichotomy among ENT surgeons between soft versus unrestricted diets following tonsillectomy. A systematic review in this month's issue of the best available evidence concludes no statistical difference in morbidity between the two diets; the authors recommend an unrestricted diet to encourage adequate nutrition and hydration. ${ }^{11}$

Looking to the future, a study by Nishio et al. demonstrates the efficacy and safety of adiposederived stem cells in a vocal fold paralysis model in pigs. ${ }^{12}$ Although the sample size is small, it demonstrates a proof-of-principle of the utilisation of such cells in regenerative medicine approaches in the future. ${ }^{13}$

JONATHAN FISHMAN
ROBIN YOUNGS
EDWARD FISHER
MUSHEER HUSSAIN
Senior Editors

References

1 Babakurban ST, Topal Ö, Aydin E, Hizal E, Copur S, Ekici MD. Therapeutic effect of Castellani's paint in patients with an itchy ear canal. J Laryngol Otol 2016;130:934-8

2 Cevik C, Kaya OA, Akbay E, Yula E, Yengil E, Gulmez MI et al. Investigation of demodex species frequency in patients with a persistent itchy ear canal treated with a local steroid. J Laryngol Otol 2014;128:698-701

3 Easto RH, Reddy V. A survey of ENT experience in South West Peninsula general practitioner trainees: how can post-graduate ENT training be improved? J Laryngol Otol 2016;130:893-6

4 Chin CJ, Chin CA, Roth K, Rotenberg BW, Fung K. Simulationbased otolaryngology - head and neck surgery boot camp: 'how I do it'. J Laryngol Otol 2016;130:284-90

5 Johnston DI, Selimi V, Chang A, Smith M. A low-cost alternative for nasolaryngoscopy simulation training equipment: a randomised controlled trial. J Laryngol Otol 2015;129:1101-7

6 Isaacson G, Ianacone DC, Soliman AM. Ex vivo ovine model for suspension microlaryngoscopy training. J Laryngol Otol 2016;130:939-42

7 Clark MP, Westerberg BD, Mitchell JE. Development and validation of a low-cost microsurgery ear trainer for low-resource settings. J Laryngol Otol 2016;130:954-61 
8 Avnstorp MB, Jensen PV, Dzongodza T, Matinhira N, Chidziva $\mathrm{C}$, Melchiors $\mathrm{J}$ et al. The introduction of emergency cricothyroidotomy simulation training in Zimbabwe contributed to the saving of two lives. J Laryngol Otol 2016;130: 923-7

9 Alimoglu Y, Inci E. Is hyperbaric oxygen therapy a salvage treatment option for sudden sensorineural hearing loss? J Laryngol Otol 2016;130:943-7

10 Cekin E, Cincik H, Ulubil SA, Gungor A. Effectiveness of hyperbaric oxygen therapy in management of sudden hearing loss. J Laryngol Otol 2009;123:609-12
11 Millington AJ, Gaunt AC, Phillips JS. Post-tonsillectomy dietary advice: systematic review. J Laryngol Otol 2016;130: 889-92

12 Nishio N, Fujimoto Y, Suga K, Iwata Y, Toriyama K, Takanari $\mathrm{K}$ et al. Autologous fat injection therapy including a high concentration of adipose-derived regenerative cells in a vocal fold paralysis model: animal pilot study. J Laryngol Otol 2016; 130:914-22

13 Wormald JC, Fishman JM, Juniat S, Tolley N, Birchall MA. Regenerative medicine in otorhinolaryngology. J Laryngol Otol 2015;129:732-9 